\title{
Effectiveness of Magnetite Nanopartices stabilized by 3-hydroxypyridine Derivative and Polyvinyl Pyrrolidone in Experimental Therapy of Acute Blood Loss
}

DOI: $10.17691 /$ stm2015.7.2.11

Recived November 16, 2014

Ye.M. Vazhnichaya, MD, DSC, Professor, Department of Experimental and Clinical Pharmacology';

Ye.V. Mokliak, PhD Student, Department of Experimental and Clinical Pharmacology';

A.A. Zabozlaev, PhD, Vice Director on Development ${ }^{2}$

JUkrainian Medical Stomatological Academy, 23 Shevchenko St., Poltava, 36011, Ukraine;

"Company "PHARMASOFT", 22 Avtozavodskaya St., Moscow, 115280, Russian Federation

One of the preconditions of biomedical use of iron oxide nanoparticles including magnetite is their stabilization in liquid medium, wherein the covering substances largely determine pharmacological activity and toxicity of such nanoparticles. We obtained nanofluid that contains magnetite nanoparticles stabilized with 2-ethyl-6-methyl-3-hydroxypyridine succinate (Mexidol) and polyvinyl pyrrolidone (PVP). Its anti-anemic properties have not been studied previously.

The aim of the investigation was to study the effect of magnetite nanoparticles stabilized with Mexidol and PVP on hematological parameters of laboratory animals in the norm and after acute blood loss.

Materials and Methods. Experiments were performed on 109 albino male rats. The liquid containing magnetite nanoparticles stabilized with Mexidol and PVP was administered to intact animals and rats after blood loss in the dose of $1.35 \mathrm{mg} \mathrm{Fe} / \mathrm{kg}$. Its effects were compared with the action of standard iron preparation Ferrum Lek $(1.25 \mathrm{mg} \mathrm{Fe} / \mathrm{kg})$ as a reference drug. We determined red blood cells count, total hemoglobin, hematocrit, erythrocyte indices as well as reticulocytes content in blood 3 and $72 \mathrm{~h}$ after the administration of the nanofluid and the reference preparation.

Results. Nanofluid stimulates erythropoiesis in intact animals that is characterized by the increase in red blood cells count, total hemoglobin and hematocrit, which, however, are within the normal range. In anemia induced by acute blood loss, the nanofluid helps to restore these parameters and increases significantly the number of reticulocytes in blood. In both cases, the effects of the nanofluid are more pronounced than those of the reference preparation that can be due to better bioavailability of iron in the nanofluid, with Mexidol being used as one of stabilizing agents.

Conclusion. Magnetite nanoparticles stabilized with Mexidol and PVP stimulate erythropoiesis in the norm and in acute blood loss that is potentiated by the presence of succinate-containing 3-hyroxypyridine derivative as their constituent. The efficiency of magnetite nanoparticles and the possibility to use them as nanofluid offer the prospect of developing a new pharmaceutical form to correct anemic conditions based on these nanoparticles.

Key words: magnetite nanoparticles; 3-hydroxypyridine; Mexidol; polyvinyl pyrrolidone; blood loss; anemia.

The use of nanomaterials in medicine and pharmacology make possible to control biological systems at the molecular level as well as to combine in a single preparation the diagnosis and treatment theranostics [1-3].

Among the nanoparticles intensively studied in the order to biomedical applications, is iron oxide nanoparticles, including oxide of iron (II, III), or magnetite, are particularly important. The properties of these nanoparticles determine their applicability for the visualization of some structures in magnetic resonance imaging, hyperthermia of malignant tumors, targeted drug delivery, and pharmacological correction of anemic conditions [4-7].

In the studies of iron oxide nanoparticles, there are used ferrofluids (nanofluids), colloidal suspensions of magnetic nanoparticles stabilized by surfactants in liquid medium [8] that may be a basis for creation of medicinal forms for parenteral administration [9]. In the order to stabilize iron oxide nanoparticles they are encapsulated by the forming a coating that provides resistance to oxidation, corrosion, and aggregation, as well as single-domain retains [10]. Stabilizing agents (organic, inorganic, monomeric, or polymeric) define not only the hydrodynamic size and physico-chemical properties of magnetic nanoparticles, but their biological activity, the interaction with the target cells, absorption by macrophages, and toxicity [11]. With sufficient diversity of substances for iron oxide nanoparticles coating, 3hydroxypyridine derivatives for this purpose have not been used previously, however we have obtained liquid dispersion system containing magnetite nanoparticles

For contacts: Vazhnichaya Elena Mitrofanovna, e-mail: vazhnichaya@ukr.net 
stabilized with 2-ethyl-6-methyl-3-hydroxypyridine succinate (Mexydol) and polyvinyl pyrrolidone (PVP) [12], which opens up new prospects for biomedical applications of nano-iron as well as its covering agents, in particular Mexidol.

The aim of the investigation was to study the influence of magnetite nanoparticles stabilized by Mexidol and PVP in liquid medium on hematological parameters in laboratory animals in the norm and under the conditions of acute post-hemorrhagic anemia, to assess the effectiveness of these nanoparticles by comparing of their activity with the action of anti-anemic iron preparation for parenteral use Ferrum Lek.

Materials and Methods. The experiments were performed on 109 albino male Wistar rats of $210-225 \mathrm{~g}$ of body weight, obtained from the breeding ground Biomodelservis (Kiev, Ukraine). They were organized in accordance with the rules established by the European Convention for the Protection of Vertebrate Animals Used for Experimental and Other Scientific Purposes (adopted in Strasbourg on 18.03.1986 and confirmed in Strasbourg on 15.06.2006) and received positive evaluation of the Bioethics Commission of Ukrainian Medical Stomatological Academy.

3 series of experiments were carried out. In the first series, it was studied the effect of magnetite nanoparticles stabilized by Mexidol and PVP on animal in the norm with dividing them into such groups as intact animals; animals with solvent (control); reference preparation (Ferrum Lek) or samples of nanofluid containing magnetite nanoparticles stabilized by Mexidol and PVP administration, and further investigation after 3 and $72 \mathrm{~h}$. In the second series, it was studied the effects of magnetite nanoparticles stabilized by Mexidol and PVP $3 \mathrm{~h}$, in the third series $-72 \mathrm{~h}$ after the acute blood loss. In these two series, there were following groups: intact animals; blood loss with solvent administration (without pharmacological correction); blood loss with the administration of reference preparation or liquid dispersion system containing magnetite nanoparticles stabilized by Mexidol and PVP (hereinafter referred to as "nanofluid"). Acute blood loss was modeled by the cardiac puncture under ether general anesthesia and removal of $25 \%$ of circulating blood [13].

For the preparation of nanofluid we used the condensate of magnetite nanoparticles $\left(\mathrm{Fe}_{3} \mathrm{O}_{4}\right)$ of USPIO (ultra small particles of iron oxide) class with the size of $5-8 \mathrm{~nm}$ deposited towards the vapor stream on the crystals of sodium chloride by electron beam technology in vacuum (Paton Electric Welding Institute of NAS of Ukraine, Kiev, Ukraine) [14]. This powder had the following composition (in weight \%): iron - 26.9\%; sodium - $22.5 \%$; chlorine - $34.4 \%$; oxygen $-16.2 \%$. For solubilization and stabilization of magnetite nanoparticles in aqueous medium it was used substance 2-ethyl-6-methyl-3-hydroxypyridine succinate known as drug Mexidol and has antioxidant, antihypoxic, and anxiolytic effects [15] obtained from the manufacturer (Bion, Russia). Together with Mexidol to stabilize magnetite nanoparticles we used polyvinyl pyrrolidone (PVP, povidone) with molecular weight of $8.0 \pm 2.0 \mathrm{kDa}$ (Sintvita, Russia) [16]. The dispersion containing the listed ingredients in a ratio of $1 \mathrm{mg}$ of magnetite nanoparticles condensate, $20 \mathrm{mg}$ of Mexidol, and $30 \mathrm{mg}$ of PVP in $1 \mathrm{ml}$, was prepared ex tempore, using as solvent a liquid which contains $2.75 \mathrm{~g}$ of sodium chloride, $0.21 \mathrm{~g}$ of potassium chloride, $0.25 \mathrm{~g}$ of calcium chloride, $0.00025 \mathrm{~g}$ of magnesium chloride, $0.115 \mathrm{~g}$ of sodium bicarbonate and distilled water to $1 \mathrm{~L}$. For this $3 \%$ solution of PVP in the above mentioned solvent was added aseptically to the mixture of powders of magnetite nanoparticles and Mexidol substance, stirred, heated for $2 \mathrm{~h}$ at $60^{\circ} \mathrm{C}$ and cooled to room temperature $\left(20^{\circ} \mathrm{C}\right)$. According to photon correlation spectroscopy, nanofluid prepared in this manner contains particles with the hydrodynamic size of $30-40 \mathrm{~nm}$ in a predominant amount (99.9\% of total particles count) [12]. Samples of nanofluids were administered intraperitoneally to the animals immediately after the blood loss in the volume of $1 \mathrm{ml}$. The dose of elemental iron was $1.35 \mathrm{mg} \mathrm{Fe} / \mathrm{kg}$ body weight. As a reference preparatiobn Ferrum Lek (Lek, Slovenia) at the dose of $1.25 \mathrm{mg} \mathrm{Fe} / \mathrm{kg}$ body weight [17] was injected similarly.

The animals were taken from the experiment 3 and $72 \mathrm{~h}$ after the blood loss and at the same term after the administration of nanofluid to intact albino rats. Euthanasia was performed under ether general anesthesia by blood removal from the heart to stop it.

In the blood from the heart it was determined total red blood cells count (RBC), hematocrit (Hct), total hemoglobin $(\mathrm{Hb})$, mean corpuscular volume (MCV), mean corpuscular hemoglobin concentration (MCHC), mean corpuscular hemoglobin amount $(\mathrm{MCH})$, as well as anisocytosis index - the width of the distribution curve of erythrocytes (RDW) via MicroCC-20Plus Vet (High Technology Inc., USA) hematology analyzer (Switzerland) [18]. Reticulocytes content in the blood was studied by supravital staining with methylene blue followed by cells counting in smears by microscope AmScope T490B-10MT (United Scope LLC, USA) with $\times 100$ lens [19].

The resulting digital material was statistically processed using standard software package Statistica for Windows 8.0. It was calculated the mean $\mathrm{M}$, it standard error $m$ and evaluated the significance of differences between groups using one-way ANOVA analysis with post hoc test Fisher LSD.

Results. In the first series of experiments it is determined that hematologic parameters in control animals injected with solvent were not different from those in the intact albino rats (Table 1). $3 \mathrm{~h}$ after the administration of etalon anti-anemic preparation Ferrum Lek to intact animals RBC and Hct values were at the level of control, and $\mathrm{Hb}$ increased by $11 \%(\mathrm{p}=0.0054)$. In this 
Ta ble 1

The influence of nanofluid containing magnetite nanoparticles stabilized by Mexidol and PVP on haematological parameters of intact animals $(M \pm m)$

\begin{tabular}{|c|c|c|c|c|c|c|c|c|}
\hline Term & Groups of animals & $\operatorname{RBC}\left(\times 10^{12} / \mathrm{L}\right)$ & $\mathrm{Hb}(\mathrm{g} / \mathrm{L})$ & Hct (units) & $\operatorname{MCV}\left(\mu m^{3}\right)$ & MCH (pg) & MCHC (g/dl) & RDW (\%) \\
\hline 3 and $72 \mathrm{~h}$ & Intact $(n=5)$ & $6.94 \pm 0.29$ & $129.0 \pm 3.3$ & $0.39 \pm 0.01$ & $57.3 \pm 0.9$ & $17.8 \pm 0.4$ & $317.2 \pm 6.8$ & $10.1 \pm 0.3$ \\
\hline \multirow{3}{*}{$3 \mathrm{~h}$} & Solvent (control) $(n=5)$ & $6.98 \pm 0.29$ & $128.2 \pm 3.6$ & $0.40 \pm 0.01$ & $57.4 \pm 1.1$ & $17.7 \pm 0.3$ & $316.4 \pm 7.7$ & $10.0 \pm 0.4$ \\
\hline & Ferrum Lek $(n=5)$ & $6.95 \pm 0.17$ & $142.0 \pm 2.6^{*+}$ & $0.40 \pm 0.01$ & $57.6 \pm 0.5$ & $20.4 \pm 0.1^{\star+}$ & $355.2 \pm 4.2^{\star+}$ & $9.1 \pm 0.2^{\star+}$ \\
\hline & Nanofluid $(n=5)$ & $8.17 \pm 0.11^{\star+v}$ & $142.8 \pm 1.5^{\star+}$ & $0.47 \pm 0.01^{\star+v}$ & $57.9 \pm 0.8$ & $17.4 \pm 0.3^{v}$ & $301.6 \pm 2.5^{v}$ & $9.3 \pm 0.5$ \\
\hline \multirow{3}{*}{$72 \mathrm{~h}$} & Solvent (control) $(n=5)$ & $6.95 \pm 0.29$ & $128.8 \pm 3.3$ & $0.39 \pm 0.01$ & $57.5 \pm 1.0$ & $17.6 \pm 0.3$ & $317.4 \pm 7.8$ & $10.0 \pm 0.3$ \\
\hline & Ferrum Lek $(n=5)$ & $6.96 \pm 0.16$ & $148.0 \pm 2.5^{\star+}$ & $0.41 \pm 0.01$ & $58.7 \pm 0.5$ & $21.5 \pm 0.3^{*+}$ & $362.0 \pm 2.4^{\star+}$ & $8.8 \pm 0.3^{\star+}$ \\
\hline & Nanofluid $(n=5)$ & $8.10 \pm 0.30^{\star+v}$ & $144.4 \pm 4.5^{\star+}$ & $0.47 \pm 0.01^{\star+v}$ & $58.0 \pm 1.1$ & $17.8 \pm 0.4^{v}$ & $307.8 \pm 3.3^{v}$ & $9.3 \pm 0.3$ \\
\hline
\end{tabular}

N o t e: * statistically significant differences in the values $(p<0.05)$ compared to intact animals; ${ }^{+}$group "solvent" (control); ${ }^{v}$ group "Ferrum Lek". RBC: total count of red blood cells; Hb: total hemoglobin; Hct: hematocrit; MCV: mean corpuscular volume; MCH: mean content of hemoglobin; MCHC: mean concentration of hemoglobin; RDW: "distribution width" of red blood cells (anisocytosis index).

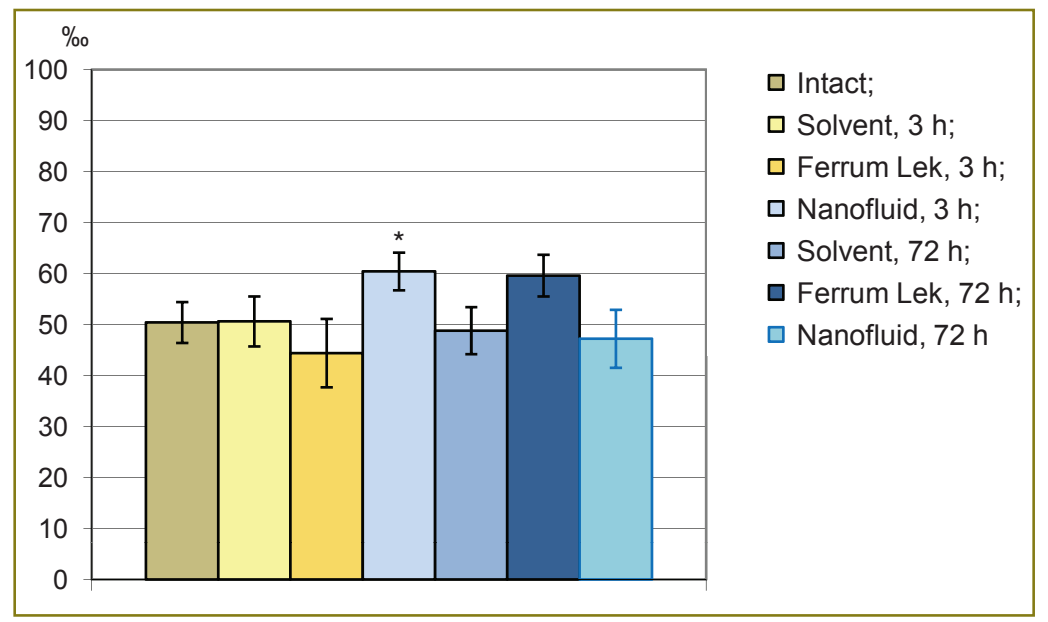

Figure 1. The content of reticulocytes in the blood 3 and $72 \mathrm{~h}$ after the administration of nanofluid containing magnetite nanoparticles stabilized by Mexidol and PVP to intact animals; * statistically significant differences in the values compared to the group "Ferrum Lek, $3 \mathrm{~h}$ " $(p<0.05)$

time of observation, Ferrum Lek increased erythrocyte indices: $\mathrm{MCH}(\mathrm{p}=0.0001)$ and $\mathrm{MCHC}(\mathrm{p}=0.0002)$ as compared to control. Administration of intact rats with fluid containing magnetite nanoparticles stabilized by Mexidol and PVP was characterized by an increase in RBC by $17 \%(p=0.0016), \mathrm{Hb}-$ by $11 \%(p=0.0036)$ and $\mathrm{Hct}$ - by $17.5 \%(\mathrm{p}=0.0001)$ as compared to control (See Table 1). This is significantly higher than values of RBC and Hct on the background of reference preparation action ( $p=0.0016$ and $p=0.0001$ respectively). Nanofluid also caused a tendency to lowering of $\mathrm{MCHC}$ index $(p=0.084)$ as compared to control. This parameter was lower than the saturation of erythrocytes by hemoglobin under the conditions of reference drug administration $(p=0.0001)$. Other indices did not change.

$72 \mathrm{~h}$ after the administration of Ferrum Lek to intact albino rats it was registered the increase of $\mathrm{Hb}$
( $p=0.0012)$ in comparison with control on the background of unchanged RBC and Hct (See Table 1). Erythrocyte indices in this period after the administration of Ferrum Lek to intact animals were characterized by the increase of $\mathrm{MCH}$ $(p=0.0001)$ and $\mathrm{MCHC}(p=0.0001)$ as well as by the reduction of RDW ( $p=0.0135)$. In this term of observation, nanofluid use caused the increase of RBC by $16 \%$ $(\mathrm{p}=0.0082)$, Hct - by $18 \%(\mathrm{p}=0.0001)$ and $\mathrm{Hb}-$ by $13 \%(\mathrm{p}=0.0058)$ as compared to control. Changes in the count of red blood cells and hematocrit under the influence of nanoparticles were more pronounced than those in the use of reference preparation $(p=0.0085$ and $p=0.0013$ respectively). On the background of nanofluid action erythrocyte indices stayed at the level of control, but the saturation of red blood cells by hemoglobin ( $\mathrm{MCH}$ and $\mathrm{MCHC}$ ) was lower than that under the influence of reference preparation Ferrum Lek $(p=0.0001)$.

In the intact animals, Ferrum Lek administration did not affect the content of reticulocytes in the blood $3 \mathrm{~h}$ after injection (Figure 1). After the application of nanofluid, this parameter also did not differ from control, but was higher than that in Ferrum Lek use $(p=0.0369) .72 \mathrm{~h}$ after the administration both reference iron preparation and stabilized magnetite nanoparticles, reticulocytes content in the blood of intact animals remained at the control level.

In the second series of experiments, blood loss with solvent administration (without pharmacological correction) was accompanied by a decline in the main parameters of the "red" blood (Table 2). $3 \mathrm{~h}$ after its, values of $\mathrm{RBC}, \mathrm{Hb}$, and $\mathrm{Hct}$ decreased by 30,29 and $27 \%(p=0.0001)$, but erythrocyte indices did not 
Ta ble 2

The influence of nanofluid containing magnetite nanoparticles stabilized by Mexidol and PVP on hematological parameters of animals after acute blood loss $(\mathrm{M} \pm \mathrm{m})$

\begin{tabular}{|c|c|c|c|c|c|c|c|c|}
\hline Term & Groups of animals & $\operatorname{RBC}\left(\times 10^{12} / \mathrm{L}\right)$ & $\mathrm{Hb}(\mathrm{g} / \mathrm{L})$ & Hct (units) & $\operatorname{MCV}\left(\mu m^{3}\right)$ & MCH (pg) & $\operatorname{MCHC}(g / d l)$ & RDW (\%) \\
\hline \multirow{4}{*}{$3 \mathrm{~h}$} & Intact $(n=13)$ & $7.61 \pm 0.12$ & $135.2 \pm 2.9$ & $0.44 \pm 0.01$ & $57.6 \pm 1.5$ & $17.8 \pm 0.5$ & $311.6 \pm 11.6$ & $10.5 \pm 0.5$ \\
\hline & Blood loss + solvent $(n=8)$ & $5.32 \pm 0.19^{*}$ & $95.5 \pm 4.0^{*}$ & $0.32 \pm 0.01^{*}$ & $58.6 \pm 1.3$ & $17.1 \pm 0.3$ & $294.1 \pm 7.9$ & $9.7 \pm 0.4$ \\
\hline & Blood loss + Ferrum Lek $(n=9)$ & $5.83 \pm 0.16^{*}$ & $111.7 \pm 6.1^{*+}$ & $0.35 \pm 0.01^{*}$ & $59.2 \pm 1.3$ & $19.0 \pm 0.7^{+}$ & $315.6 \pm 17.9$ & $10.9 \pm 0.7$ \\
\hline & Blood loss + nanofluid $(n=10)$ & $6.40 \pm 0.21^{*+v}$ & $110.0 \pm 2.8^{*+}$ & $0.36 \pm 0.01^{*+}$ & $55.7 \pm 1.2$ & $16.9 \pm 0.3^{v}$ & $303.4 \pm 6.2$ & $9.7 \pm 0.2$ \\
\hline \multirow{4}{*}{$72 \mathrm{~h}$} & Intact $(n=9)$ & $7.58 \pm 0.20$ & $133.3 \pm 2.7$ & $0.43 \pm 0.01$ & $59.9 \pm 1.4$ & $17.5 \pm 0.5$ & $293.2 \pm 11.6$ & $10.9 \pm 0.7$ \\
\hline & Blood loss + Solvent $(n=8)$ & $6.18 \pm 0.12^{*}$ & $122.4 \pm 2.8$ & $0.36 \pm 0.01^{*}$ & $60.1 \pm 0.3$ & $19.7 \pm 0.6$ & $331.9 \pm 12.6$ & $9.7 \pm 0.2$ \\
\hline & Blood loss + Ferrum Lek $(n=7)$ & $6.35 \pm 0.18^{*}$ & $108.9 \pm 9.8^{*}$ & $0.39 \pm 0.01^{*}$ & $62.7 \pm 2.4$ & $17.5 \pm 1.6$ & $283.6 \pm 32.1$ & $10.6 \pm 0.5$ \\
\hline & Blood loss + nanofluid $(n=10)$ & $6.66 \pm 0.17^{*}$ & $127.3 \pm 5.0^{v}$ & $0.39 \pm 0.01^{*+}$ & $60.4 \pm 0.6$ & $18.9 \pm 1.1$ & $332.0 \pm 17.6$ & $10.1 \pm 0.3$ \\
\hline
\end{tabular}

N o t e: * statistically significant differences in the values $(p<0.05)$ compared to intact animals; ${ }^{+}$group "blood loss + solvent"; "group "blood loss + Ferrum Lek". RBC: total count of red blood cells; Hb: total hemoglobin; Hct: hematocrit; MCV: mean corpuscular volume; $\mathrm{MCH}$ : mean content of hemoglobin; $\mathrm{MCHC}$ : mean concentration of hemoglobin; RDW: "distribution width" of red blood cells (anisocytosis index).

change as compared to those of intact animals. The administration of reference preparation Ferrum Lek to rats with bloodloss increased $\mathrm{Hb}$ by $17 \%(\mathrm{p}=0.0117)$ as compared to pathology without pharmacological correction. This occurred against the backdrop of tendency to rising of RBC $(p=0.083)$ and $(p=0.075)$. The administration of standard iron preparation contributed to the increase of $\mathrm{MCH}(p=0.03)$ versus blood loss without pharmacological correction. Magnetite nanoparticles stabilized by Mexidol and PVP, at this stage of observations, provided the increase in RBC by $20 \%(p=0.0004)$ and $\mathrm{Hb}$ by $15 \%(\mathrm{p}=0.0197)$, as well as enhanced Hct by $13 \%(p=0.018)$ as compared to blood loss without pharmacological correction. At the same, time they did not affect erythrocyte indices as compared with pathologic background. Moreover, the number of red blood cells and the index of $\mathrm{MCH}$ significantly differ from the same parameters in the administration of reference preparation: upward $(p=0.0407)$ or decrease $(p=0.012)$ respectively.

$3 \mathrm{~h}$ after the blood loss without pharmacological correction, reticulocytes count in blood was the same as that in the intact animals (Figure 2). Ferrum Lek administration helped to improve this parameter $(p=0.0428)$ as compared to pathological background. Under these conditions, nanofluid did not cause statistically significant changes in the number of reticulocytes in the blood as compared to intact animals, blood loss without pharmacological correction and blood loss with the administration of the reference preparation.

At $72 \mathrm{~h}$ after the blood loss with solvent administration (the third series) means of RBC and Hct remained reduced by 18 and $16 \%(p=0.0001)$ respectively as compared to the intact animals (See Table 2). Development of compensatory reactions in this period after blood loss was characterized by the tendency to lowering of RDW $(p=0.088)$ with no other changes of erythrocyte indices.

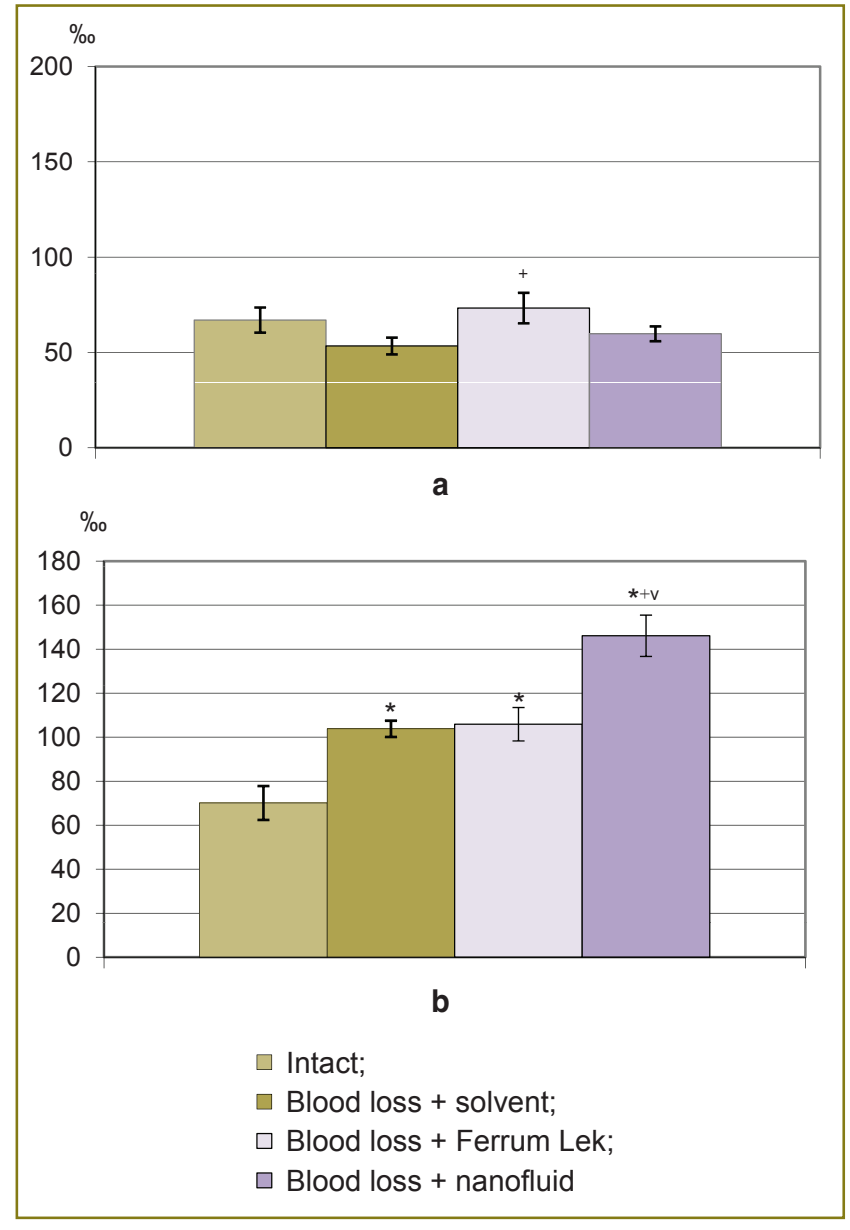

Figure 2. The content of reticulocytes in the blood of animals 3 (a) and $72 \mathrm{~h}$ (b) after the acute blood loss with administration of nanofluid containing magnetite nanoparticles stabilized by Mexidol and PVP; * statistically significant differences in the values $(p<0.05)$ compared to intact animals; ${ }^{+}$group "blood loss + solvent" (without pharmacological correction); v group "blood loss + Ferrum Lek" 
Using the reference preparation Ferrum Lek tends to increase Hct $(p=0.095)$ without changes of RBC and $\mathrm{Hb}$ compared to blood loss without pharmacological correction. Influence of nanofluid at this stage of acute blood loss compensation was characterized by tendency to increase in RBC ( $p=0.0555)$ and a statistically significant increase in Hct $(p=0.0287)$ with no changes of $\mathrm{Hb}$ as compared to pathological condition. At the same time, the values of $\mathrm{Hb}$ under the administration of nanofluid were significantly higher $(p=0.022)$ than under the use of Ferrum Lek. Both reference preparation and magnetite nanoparticles stabilized by Mexidol and PVP in the given period of observation did not influence the status of erythrocyte indices.

$72 \mathrm{~h}$ after the blood loss with solvent administration reticulocytes content in the blood of experimental animals was $48 \%$ greater than the same in the intact group $(p=0.0048)$ (See Figure 2). In this term, when blood loss was treated with Ferrum Lek reticulocytes count was at the level of the model pathology without correction. At the same time after the application of nanofluid it increased by $41 \%$ as compared to the uncorrected blood loss $(p=0.0005)$, that was significantly higher than analogical parameter onr the background of Ferrum Lek actionb $(p=0.0012)$.

Discussion. The results obtained showed that the fluid containing magnetite nanoparticles stabilized with Mexidol and PVP stimulates erythropoiesis in the intact animals. This is manifested in $3 \mathrm{~h}$ after the administration, is maintained within the next $72 \mathrm{~h}$ and is characterized by increased levels of RBC, $\mathrm{Hb}$ and $\mathrm{Hct}$, which, however, did not go beyond the norm [20]. It is noteworthy that under the similarity of administered doses of iron nanofluid's effect on the count of erythrocytes and hematocrit was more pronounced than that under the use of Ferrum Lek. $3 \mathrm{~h}$ after the injection, reticulocytes content in the blood of animals treated with nanofluid also was higher. This development of processes suggested that stabilizing agents, especially Mexidol, impart to studied composite nanoparticles the additional ability to stimulate erythroid cells division and maturation in the bone marrow. This assumption is consistent with the published data on the mieloprotective properties of Mexidol in the irradiation and its stimulatory effect on erythropoiesis in acute post-hemorrhagic anemia [21, 22]. Predominant increase in the count of erythrocytes at the same $\mathrm{Hb}$ level in the nanofluid administration to intact albino rats also can explain the fact that saturation of red blood cells by hemoglobin in this case was lower than after Ferrum Lek applying.

Modeling of acute blood loss was accompanied by a decrease in the level of $\mathrm{RBC}$, $\mathrm{Hct}$ and $\mathrm{Hb}$ without altering of erythrocyte indices, that evidence of normochromic, normocytic character of anemia and consistent with the literature data [23]. It was possible to think that it is typical, if changes in the content of reticulocytes in the animals' blood are absent $3 \mathrm{~h}$ after the blood loss when there is hyperhydremic phase of blood loss compensation, and increasing at $72 \mathrm{~h}$ when the bone marrow phase of compensation occurs [24].

In acute blood loss, the effect of magnetite nanoparticles stabilized by Mexidol and PVP as well as the action of the reference iron preparation was more expressed $3 \mathrm{~h}$ after the moment of blood loss. In this, nanofluid caused more intensive recovery of red blood cells count as compared to Ferrum Lek, which obviously has the same nature as the analogical effects in the erythron system of intact animals injected with stabilized magnetite nanoparticles. In light of this assumption is contradictory the fact that in the early period of observation nanofluid caused no increase in the amount of reticulocytes in the blood, as observed in the case of the reference iron preparation use. Based on the rate of maturation of erythroid cells and acceleration of erythropoiesis under the stress conditions $[25,26]$ it is possible to suggest that magnetite nanoparticles stabilized by Mexidol and PVP accelerate the transformation of reticulocytes to erythrocytes, which creates the illusion of unchanged erythron regenerative response in comparison with control pathology. It is also possible that substance forming a coating of magnetite nanoparticles contribute to the output of red blood cells in circulation influencing microvasculature of bone marrow and other depots, as it is observed under their action in other tissues [27, 28].

$72 \mathrm{~h}$ after the blood loss, state of the main parameters of the "red" blood on the background of treatment by used remedies (except hematocrit for the administration of nanofluid) did not differ from that in the natural development of compensatory reactions and did not reach the initial level. We believe that this can be explained by a single dose of pharmacological correction and a relatively low dose of injected iron. At the same time, it should be noted that during treatment with magnetite nanoparticles stabilized by Mexidol and PVP $\mathrm{Hb}$ was higher than under the use of Ferrum Lek, which may be due to their greater bioavailability due to nanosize as well as due to presence in the particles succinate-containing 3-hydroxypyridine derivative able to participate in mitochondrial processes [29] where the heme is synthesized [30]. The increase after $72 \mathrm{~h}$ in the content of reticulocytes in the blood of animals which were administered with nanofluid for correcting of blood loss indicates that the tested nanoparticles are able not only to stimulate the transformation of reticulocytes into mature erythrocytes, as assumed with respect to the previous period of observation, but also can activate the regeneratory reaction of marrow erythroid cells at more early stages.

Conclusion. Magnetite nanoparticles stabilized in the liquid medium by 2-ethyl-6-methyl-3-hydroxypyridine succinate (Mexidol) and polyvinyl pyrrolidone (PVP) in the dose of $1.35 \mathrm{mg} \mathrm{Fe} / \mathrm{kg}$ body weight stimulates erythropoiesis in the intact animals and activate the regeneratory reaction of erythron in anemia due to acute 
blood loss. These nanoparticles are more effective than traditional iron preparation Ferrum Lek in the comparable dose. This advantage and the possibility to use them as nanofluid offer the promise of developing a new medicinal formulation for the correction of anemic conditions.

Acknowledgments. The authors express their gratitude to Yu.A. Kurapov, PhD, Head of Electronbeam Nanotechnology Department of the Paton Electric Welding Institute of NAS of Ukraine, for providing of the initial condensate of magnetite nanoparticles and the data on its physicochemical characteristics.

Study Funding and Conflict of Interests. The study was not funded by any sources, and conflicts of interests related to this study are absent.

\section{References}

1. Mclntyre R.A. Common nano-materials and their use in real world applications. Sci Prog 2012; 95(Pt 1): 1-22, http:// dx.doi.org/10.3184/003685012x13294715456431.

2. Nikiforov V.N. Biomedical applications of magnetic nanoparticles. Nauka i tehnologii v promyishlenosti 2011; 1 : 90-99.

3. Urban C., Urban A.S., Charron H., Joshi A. Externally modulated theranostic nanoparticles. Transl Cancer Res 2013; 2(4): 292-308, http://dx.doi.org/10.3978/j.issn.2218676X.2013.08.05.

4. Zhao X., Zhao H., Chen Z., Lan M. Ultrasmall superparamagnetic iron oxide nanoparticles for magnetic resonance imaging contrast agent. J Nanosci Nanotechnol 2014; 14(1): 210-220, http://dx.doi.org/10.1166/jnn.2014. 9192.

5. Laurent S., Saei A.A., Behzadi S., Panahifar A., Mahmoudi M. Superparamagnetic iron oxide nanoparticles for delivery of therapeutic agents: opportunities and challenges. Expert Opin Drug Deliv 2014; 11(9): 1449-1470, http://dx.doi. org/10.1517/17425247.2014.924501.

6. Wang S.Y., Liu M.C., Kang K.A. Magnetic nanoparticles and thermally responsive polymer for targeted hyperthermia and sustained anti-cancer drug delivery. Adv Exp Med Biol 2013; 765: 315-321, http://dx.doi.org/10.1007/978-1-46144989-8_44.

7. Rosner M.H., Auerbach M. Ferumoxytol for the treatment of iron deficiency. Expert Rev Hematol 2011; 4(4): 399-406, http://dx.doi.org/10.1586/ehm.11.31.

8. Yoon M., Tománek D.J. Equilibrium structure of ferrofluid aggregates. J Phys Condens Matter 2010; 22(45): 455105, http://dx.doi.org/10.1088/0953-8984/22/45/455105.

9. Liu J., Sun Z., Deng Y., Zou Y., Li C., Guo X., Xiong L., Gao Y., Li F., Zhao D. Highly water-dispersible biocompatible magnetite particles with low cytotoxicity stabilized by citrate groups. Angew Chem Int Ed Engl 2009; 48(32): 5875-5879, http://dx.doi.org/10.1002/anie.200901566.

10. Behrens S. Preparation of functional magnetic nanocomposites and hybrid materials: recent progress and future directions. Nanoscale 2011; 3: 877-892, http://dx.doi. org/10.1039/c0nr00634c.

11. Simberg D., Park J.H., Karmali P.P., Zhang W.M., Merkulov S., McCrae K., Bhatia S.N., Sailor M., Ruoslahti E. Differential proteomics analysis of the surface heterogeneity of dextran iron oxide nanoparticles and the implications for their in vivo clearance. Biomaterials 2009; 30(23-24): 39263933, http://dx.doi.org/10.1016/j.biomaterials.2009.03.056.
12. Vazhnichaya Ye.M., Mokliak Ye.V., Movchan B.A., Kurapov Yu.A., Zabozlaev A.A. Sposob polucheniya biologicheski aktivnoy nanozhidkosti na osnove nanochastits oksida zheleza (II, III) i proizvodnogo 3-gidroksipiridina [Method of obtaining of biologically active nanofluid on the base of iron oxide (II, III) nanoparticle and 3-hydroxypyridine derivative]. Patent RU 2493857. 2012.

13. Doklinicheskie issledovaniya lekarstvennyih sredstv [Preclinical investigations of medicinal drugs]. Edited by Stefanov O.V. Kiev: Avitcena; 2001; 528 p.

14. Paton B.Ye., Movchan B.A., Kurapov Yu.A., Yakovchuk K.Yu. Sposob polucheniya nanochastits sistemy metall-kislorod s zadannym sostavom, elektronno-luchevym ispareniem $i$ kondensatsiey $v$ vakuume [Method of obtaining nanoparticles of metal-oxygen system with given composition by electron beam evaporation and condensation in vacuum]. Patent UA 92556. 2009.

15. Meksidol: instruktsiya, opisanie [Mexidol: instruction, description], http://health.mail.ru/drug/mexidol/.

16. Polivinilpirrolidon nizkomolekulyarnyy meditsinskiy $8000 \pm 2000$ [Polyvinylpyrrolidone of low molecular weight medicinal 8000 \pm 2000$]$. ФСП 42-0345-4367-03: PN002600/012003, http://www.sintvita.ru/docs/povidone8000.pdf.

17. Ferrum Lek: instruktsiya, opisanie [Ferrum Lek: instruction, description], http://it-apharm.ru/ferrum_lek.html.

18. Antonov V.S., Bogomolova N.V., Volkov A.S. Automatization of hematological analysis. Spravochnik zaveduyushchego kliniko-diagnosticheskoy laboratoriey 2010; 1, http://www.mcfr.ru/journals/41/256/17837/.

19. Metody klinicheskikh laboratornykh issledovaniy [Methods of clinical laboratory investigations]. Edited by Kamyishnikov V.S. Moscow: MEDpress-inform; 2013; 736 p.

20. Giknis M.L.A., Clifford Ch.B. Clinical laboratory parameters for Crl:Wl(Han). Charles River Laboratories 2008, http://www.criver.com/files/pdfs/rms/wistarhan/rm_rm_r_ wistar_han_clin_lab_parameters_08.aspx.

21. Moroz B.B., Deshevoi lu.B., Sukoian G.V., Voronina T.A., Lyrshchikova A.V., Lebedev V.G. The influence of Mexidol on post-radiation recovery of hemopoietic system. Radiats Biol Radioecol 2009; 49(1): 90-96.

22. Vlasenko N.O., Vazhnicha O.M. The influence of 2-ethyl-6-methyl-3-oxypyridine succinate on regenerative reaction of erythron at an acute blood loss. Farmatsevtichniy chasopis 2013; 1(25): 181-185.

23. Pogorelov V.M., Kozinets G.I., Kovaleva L.G. Laboratorno-klinicheskaya diagnostika anemiy [Laboratory and clinical diagnosis of anemias]. Moscow: MIA; 2004; 173 p.

24. Patofiziologiya. T. 2 [Pathophysiology. Vol. 2]. Edited by Novitskiy V.V., Goldberg E.D., Urazova O.I. Moscow: GEOTAR-Media 2009; 640 p.

25. Rumyantsev A.G., Morschakova E.F., Pavlov A.D. Eritropoetin $v$ diagnostike, profilaktike $i$ lechenii anemiy [Erythropoietin in the diagnosis, prevention and treatment of anemias]. Moscow; 2003; 448 p.

26. Paulson R.F., Shi L., Wu D.C. Stress erythropoiesis: new signals and new stress progenitor cells. Curr Opin Hematol 2011; 18(3): 139-145, http://dx.doi.org/10.1097/ MOH.0b013e32834521c8.

27. Karpikova N.I., Peteryuhina A.A. Use of the preparation Mexidol for the treatment of patients with cerebrovascular diseases of the brain. Bulleten' eksperimental'noj biologii $i$ mediciny 2006; Suppl. 1: 32-33.

28. Neogemodez: instruktsiya po primeneniyu $i$ otzyvy 
[Neohemodes: instruction for use and feedback], https://health. mail.ru/drug/neohemodez.

29. Lukyanova L.D., Germanova E.L., Tsybina T.A., Chernobaeva G.N. Energotropic effect of succinate-containing derivatives of 3-hydroxypyridine. Bulleten' eksperimental'noj biologii i mediciny 2009; 147(10): 388-392.

30. Iron and heme metabolism, http://themedicalbiochemistrypage.org/heme-porphyrin.php. 